\title{
NEED OF DEVELOPING INFORMATION SYSTEMS OF MANAGING A TECHNOLOGY LIFECYCLE OF INDUSTRIAL ENTERPRISES
}

\author{
A.V. Hollay, alexander@hollay.ru \\ South Ural State University, Chelyabinsk, Russian Federation
}

\begin{abstract}
The following article is aimed at justifying the need of developing new information systems of managing a lifecycle of technologies in order to increase the efficiency of industrial enterprise performance. This necessity was caused by the objective processes happening in the world, specifically globalization of the world economy and further specialization of labour which led to segregation of production facilities from R\&D centers developing new types of products and doing market research. In this regard, the competitiveness of industrial enterprises is now primarily to be defined by the efficiency of the technologies used in the production process. However, nowadays the vast majority of information systems are aimed not at managing technologies, but at managing products.

The author shows the common ground and differences between the management systems of a product lifecycle and management systems of a technology lifecycle as well as what competitive advantages industrial enterprises will get implementing management systems of a technology lifecycle. At the same time, the transition into such system should not have a revolutionary nature. It can be implemented due to the improvement of the available information systems, with shifting the focus on improving the existing technologies and creating new ones. Upon such transition, industrial enterprises will keep the available competences in developing new types of products and will receive an additional impulse of development due to the increase in efficiency of the technologies used.
\end{abstract}

Keywords: information systems, technologies, management, industry, enterprise management, technology lifecycle management of technology lifecycle.

\section{Introduction}

Now due to globalization of the world economy, there is a stiffer competition among industrial enterprises [1]. One of the ways to increase the performance efficiency is to implement information systems allowing the management to make justified managerial decisions [2]. However, the introduction of modern information systems does not guarantee the success of the enterprise in the market yet. To ensure the efficiency of their implementation, it is necessary to carefully approach the choice of software products, to consider specific nature of tasks solved and to devise a strategy of informatization of the enterprise.

\section{Product lifecycle}

The concept of a lifecycle (of enterprises, goods, technologies, etc.) is widely used to describe the phenomena occurring in social and economic systems [3]. The largest set of models is presented by the models of an enterprise lifecycle [4]. Next, there are the models of a product lifecycle [5], and models of information systems lifecycles are described the best in this category [6]. The models of a technology lifecycle are least worked through [7].

The common feature of all of them is that they begin with a 'birth' stage and finish with a 'death' stage which suggests that there is a certain objective regularity inherent in all the objects of the material world.

A Product Lifecycle is a set of processes associated with a certain product from the moment of recognizing the need in the society to its utilization (Fig. 1).

Currently the information systems of a product lifecycle management (PLM - Product Lifecycle Management) $[8,9]$ are widely used and aimed at considering the features of all the stages of a product 


\section{Краткие сообщения}

lifecycle. The PLM systems promote reducing the time of developing a product, accelerating its marketing and improving the quality and reliability of products. These are parts of PLM [10]:

- Product Data Management, PDM;

- Computer Aided Design, CAD;

- Computer Aided Engineering, CAE;

- Computer Aided Manufacturing, CAM;

- Computer Aided Production Planning, CAPP;

- Manufacturing Process Management, MPM;

- Digital Manufacturing, DM;

- Maintenance, Repair and Operations or Overhaul, MRO.

Although PLM solutions also include systems of production planning (Computer Aided Production Planning) and a production management systems (Manufacturing Process Management), such systems are a part of a product lifecycle management system, i.e. a production process is merely a secondary process of product development.

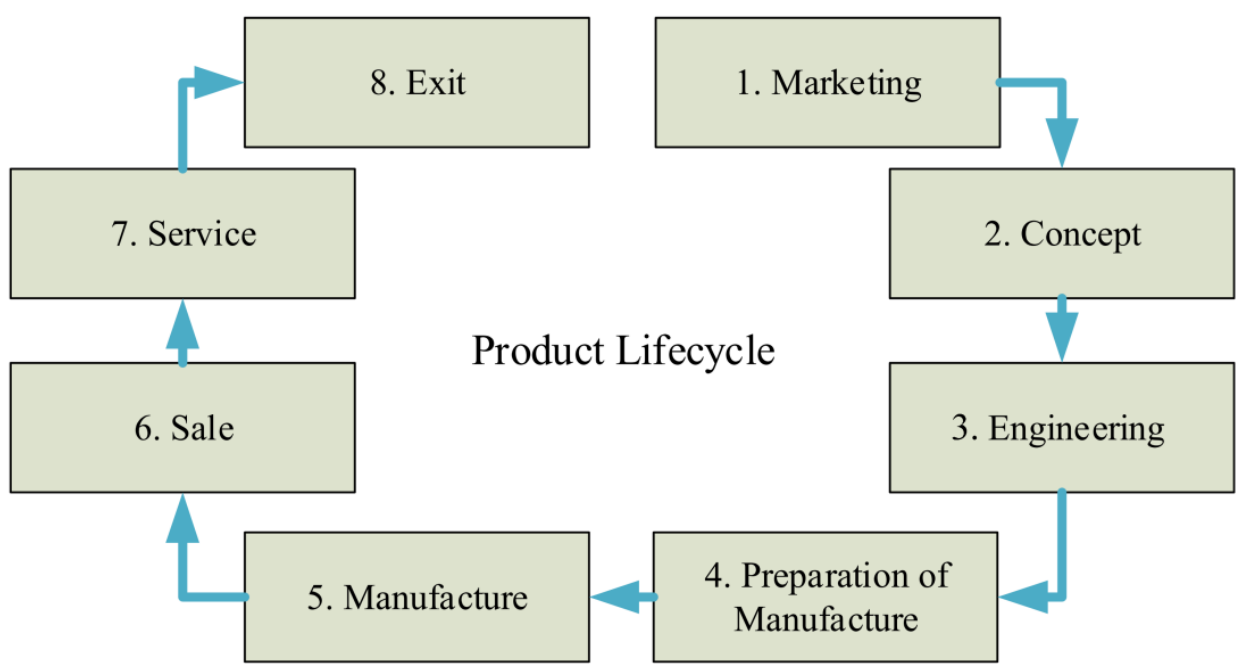

Fig. 1. Product lifecycle

Let us consider the following sequence: "Need - Product - Technology". The emergence of a new need in the market leads to the aspiration of the companies to develop new products satisfying this need and aiding making a profit. A need to make new products can cause the necessity of change in the production technology if such products cannot be made within old technological processes. The strategy of searching for new needs - developing new products - production change is convenient for the companies which are the leaders in placing new products on the market. Most often such companies are leaders in producing new types of products and own large R\&D divisions which are engaged in the analysis of the markets. At the same time, in many cases they have no own production divisions. This is usually caused by the further division of labour in the modern world and transferring production facilities to areas with cheaper labour, lower taxes, etc. At the same time, production companies have turned into production sites now and take production orders from product developers. If a new product is impossible to make with old production facilities, the developers most often just find another production company capable to fulfil this order. Thus, building a management system of an industrial enterprise only based on the concept of product lifecycle management can result in noncompetitiveness at a radical change of products.

Let us address the "Need - Product - Technology" sequence once again. It is objectively possible to say that neither the need nor the product or technology remain constant as they change over time. Three strategies of behaviour are possible, depending on what management of the company is focused on (Table 1). 
Possible behaviour strategies

Table 1

\begin{tabular}{|c|c|c|c|c|c|}
\hline \multirow{2}{*}{ No. } & \multirow{2}{*}{ Focus } & \multirow{2}{*}{ Actions } & \multirow{2}{*}{ Notes } & \multicolumn{2}{|c|}{ Production expenses } \\
\hline & & & & Advantages & Disadvantages \\
\hline 1 & Need & $\begin{array}{l}\text { Market } \\
\text { research }\end{array}$ & $\begin{array}{l}\text { As a result of a market } \\
\text { research, we define } \\
\text { the needs to satisfy which } \\
\text { new products and tech- } \\
\text { nologies of their produc- } \\
\text { tion are developed }\end{array}$ & $\begin{array}{l}\text { An opportunity to } \\
\text { develop new desired } \\
\text { products }\end{array}$ & $\begin{array}{l}\text { High costs of a market } \\
\text { research, the oversta- } \\
\text { ted cost of the product } \\
\text { made }\end{array}$ \\
\hline 2 & Product & $\begin{array}{l}\text { Developing } \\
\text { new kinds } \\
\text { of products }\end{array}$ & $\begin{array}{l}\text { Revolutionary products } \\
\text { often appear not as a result } \\
\text { of a market research, as in } \\
\text { society there are no needs } \\
\text { they can satisfy yet, but } \\
\text { as a result of scientific } \\
\text { researches. Only then new } \\
\text { products form new needs } \\
\text { for society }\end{array}$ & $\begin{array}{l}\text { Possibility of creating } \\
\text { a new market and its } \\
\text { monopolization in case } \\
\text { of success of a revolu- } \\
\text { tionary product }\end{array}$ & $\begin{array}{l}\text { High costs of develo- } \\
\text { ping products, overes- } \\
\text { timated cost of the pro- } \\
\text { duct made. Risks con- } \\
\text { nected with impossi- } \\
\text { bility of production of } \\
\text { a revolutionary pro- } \\
\text { duct using old techno- } \\
\text { logical facilities }\end{array}$ \\
\hline 3 & Technology & $\begin{array}{l}\text { Improving } \\
\text { technologies }\end{array}$ & $\begin{array}{l}\text { Improvement of technolo- } \\
\text { gies allows us to reduce } \\
\text { the production cost of } \\
\text { the existing products. } \\
\text { Significant changes in } \\
\text { technologies make it pos- } \\
\text { sible to produce new } \\
\text { products whose produc- } \\
\text { tion was impossible using } \\
\text { old technologies }\end{array}$ & $\begin{array}{l}\text { Improvement of } \\
\text { the operating tech- } \\
\text { nologies, reducing } \\
\text { the cost of the products } \\
\text { made. High competi- } \\
\text { tiveness is reached by } \\
\text { the production com- } \\
\text { panies which master } \\
\text { advanced technologies } \\
\text { first }\end{array}$ & $\begin{array}{l}\text { Lack of opportunity to } \\
\text { compete due to unique } \\
\text { goods }\end{array}$ \\
\hline
\end{tabular}

Thus, it is obvious that the needs, product and technology are interconnected and interdependent. And it is the distinctive nature of company activities which defines the focus. In particular, production of standard products is a characteristic of industrial enterprises, so the need for producing revolutionary products arises quite seldom. The competitiveness of manufacturing enterprises is generally defined by the ability to offer low production cost due to the best possible processes (technologies).

\section{A technology lifecycle}

Summing up, modern industrial enterprises which produce standard products or fulfil orders of product developers do not have considerable advantages by implementing strategies focused on needs or products. Focusing on technologies is what improves the existing technological processes.

The interrelation of lifecycles of a need, a product and technology is presented in Fig. 2.

As it was shown earlier, the concept of a lifecycle can be also applied to technologies. Most often by the stages of a technology lifecycle they mean a certain degree of maturity of technological processes: the latest technology, the advanced technology, the modern technology, the older technology, the outdated technology [11]. Dividing technologies according to this principle does not set accurate requirements to information systems of managing a technology lifecycle. Therefore we shall define the stages of technology lifecycles in a similar way to a product lifecycle (Table 2). It is clear from Table 2 that at the moment information systems in the field of engineering design of new technologies are well implemented as these systems were developed within management systems of a product lifecycle. While the systems connected with supporting the stages of technological forecasting, enhancing, replacement and exit of technology require further improvement. It should be noted that now the systems of improvement of technologies based on process approach - Business Process Management $(B P M)$ are being massively developed $[12,13]$. The interrelation of lifecycles of a need, a product and technology is presented in Fig. 2. 


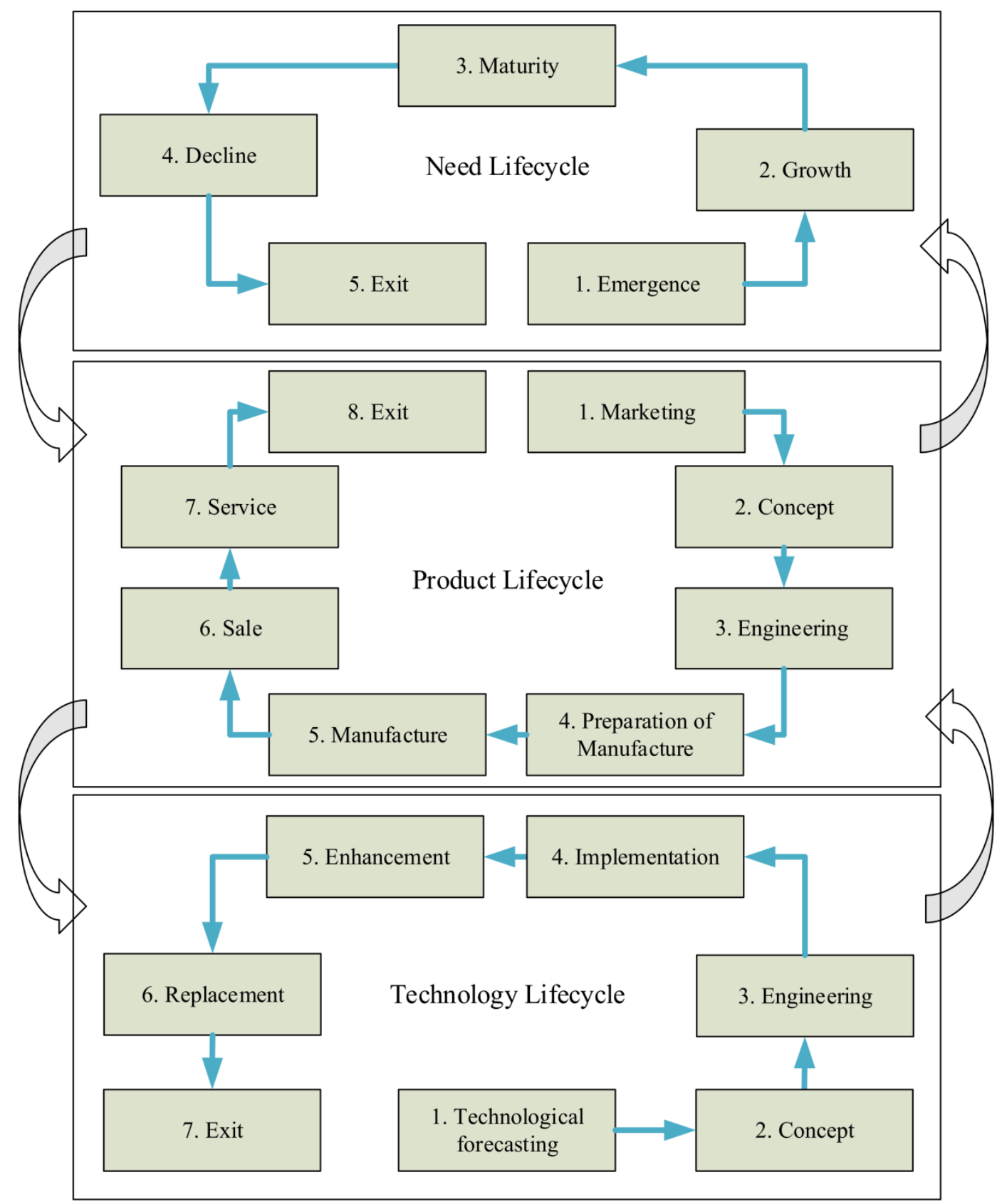

Fig. 2. Interrelation between a lifecycle of a need, a product and technology

Table 2

Stages of a technology lifecycle

\begin{tabular}{|l|l|}
\hline \multicolumn{1}{|c|}{ Stage } & \multicolumn{1}{c|}{ Content } \\
\hline $\begin{array}{l}\text { 1. Technological } \\
\text { forecasting }\end{array}$ & $\begin{array}{l}\text { Forecasting of changes in technical characteristics and forecasting of developing } \\
\text { technologies }\end{array}$ \\
\hline 2. Concept & Development of concepts of new technologies \\
\hline 3. Engineering & Design of a new technology in order to implement it in a certain enterprise \\
\hline 4. Implementation & Implementation of a new technology \\
\hline 5. Enhancement & $\begin{array}{l}\text { Any technology requires improvement and enhancement as a result of which } \\
\text { production costs decrease }\end{array}$ \\
\hline 6. Replacement & $\begin{array}{l}\text { Replacement of one technology by another one is often followed by a set of } \\
\text { structural changes in the company }\end{array}$ \\
\hline 7. Exit & Terminate utilizing a technology \\
\hline
\end{tabular}


One more drawback of aiming information systems at a product (managing a product lifecycle) is that some processes in the enterprise are not directly connected with a new product release, such as logistics, accounts department, HR, etc. Thus, these processes are often out of sight of the management and are not improved at the same time as a product. Many industrial companies failed not because they could not develop and produce new products but because the production of these products on the basis of inefficient technologies did not allow them to be competitive. Development of the information systems allowing the industrial companies to be focused on technologies will result in gaining competitive advantages.

Earlier the author [14] showed that a term 'technology' has a broad meaning and is not limited to production technologies. Development and implementation of management systems of technology lifecycles will allow us to get the effective management of all the processes of the enterprise back on track.

\section{Conclusion}

The following article the need of developing a new class of information systems, namely, management systems of a technology lifecycle which can become the basis for improving competitiveness of the enterprises is shown. Transition from management systems of a product lifecycle to management systems of a technology lifecycle is objectively necessary for further development of the industrial enterprises.

Management systems of a technology lifecycle have to include both the systems which are already available and connected with managing a product lifecycle, and the new systems necessary for improving the available technologies and developing new ones.

\section{References}

1. Loginovskiy O.V., Burkov V.N., Burkova I.V., Gelrud Ya.D., Korennaya K.A., Maksimov A.A. Upravleniye promyshlennymi predpriyatiyami: strategii, mekhanizmy, sistemy: monografiya [Management of Industrial Enterprises: Strategies, Mechanisms, Systems: Monograph]. Moscow, INFRA-M Publ., 2018. 410 p.

2. Loginovskiy O.V., Korennaya K.A. [Increasing the Efficiency of the Enterprise on the Basis of Modern Management Technologies and Information and Analytical Systems]. Avtomatizatsiya $i$ upravlenie promyshlennymi predpriyatiyami: dokl. nauch.-tekhn. konf. vseros. foruma "Informatsionnoe obshchestvo-2015: vyzovy i zadachi" [Automation and Management of Industrial Enterprises: Dokl. of Scientific-Techn. Conf. All-Russia. Forum "Information Society 2015: Challenges and Tasks"]. Chelyabinsk, South Ural St. Univ. Publ., 2015, pp. 4-38. (in Russ.)

3. Novikov D.A. Teoriya upravleniya organizatsionnymi sistemami [Theory of Management of Organizational Systems]. Moscow, Publ. of Phys. and Math. Lit., 2012. 604 p.

4. Scherbakova E.A. Sistemnyy podkhod $k$ upravleniyu zhiznennym tsiklom organizatsii [A Systematic Approach to Managing the Lifecycle of an Organization]. Production Manager, 2013, no. 3 (58), pp. 28-30. (in Russ.)

5. Pavlov N.V. Upravleniye zhiznennym tsiklom produkta [Product Lifecycle Management]. St. Petersburg, St. Petersburg Polytechnic University of Peter the Great Publ., 2014. 219 p.

6. Zaramenskikh E.P. Upravleniye zhiznennym tsiklom informatsionnykh sistem: monografiya [Information Systems Lifecycle Management: Monograph]. Novosibirsk, CRNS Publ., 2014. 270 p.

7. Kononov V.N., Zambrgitckaya E.S., Dema R.R., Kharchenko M.V. [Industrial Technology Lifecycle Management]. Bulletin of Omsk University. Series “Economics”, 2018, no. 1 (61), pp. 76-87. (in Russ.) DOI: 10.25513/1812-3988.2018.1.76-87

8. Kolchin A.F., Ovsyannikov M.V., Strekalov A.F., Sumarokov S.V. Upravleniye zhiznennym tsiklom produktsii [Product Lifecycle Management]. Moscow, Anakharsis Publ., 2002. 304 p.

9. Kulga K.S. Avtomatizatsiya tekhnicheskoy podgotovki i upravleniya proizvodstvom na osnove PLM-sistemy [Automation of Technical Training and Production Management Based on PLM-Systems]. Moscow, Mashinostroenie Publ., 2008. 275 p.

10. Saaksvuori A., Immonen A. Product Lifecycle Management. Berlin, Springer, 2008. 254 p. DOI: $10.1007 / 978-3-540-78172-1$ 
11. Martynov O.Yu. [The Lifecycle of Technology in the Production of High-tech Products]. Vector of Science of Togliatti State University, 2012, no. 1, pp. 69-72. (in Russ.)

12. Benedict T., Bilodeau N., Vitkus P., Powell E., Morrisa D. et al. BPM CBOK Version 3.0: Guide to the Business Process Management Common Body Of Knowledge. Create Space Independent Publishing Platform, 2013. 446 p.

13. Dumas M., Rosa M., Mendling J., Reijers H. Fundamentals of Business Process Management. Berlin, Springer, 2018. 527 p. DOI: 10.1007/978-3-662-56509-4

14. Hollay A.V. [The Genesis of the Concept of "Technological Development"]. Management in Modern Systems, 2018, no. 3 (19), pp. 20-24. (in Russ.)

Received 22 February 2019

Удк 005.7

DOI: $10.14529 /$ ctcr190214

\title{
НЕОБХОДИМОСТЬ РАЗРАБОТКИ ИНФОРМАЦИОННЫХ СИСТЕМ УПРАВЛЕНИЯ ЖИЗНЕННЫМ ЦИКЛОМ ТЕХНОЛОГИЙ ПРОМЫШЛЕННЫХ ПРЕДПРИЯТИЙ
}

\author{
A.В. Голлай \\ Южно-Уральский государственный университет, г. Челябинск, Россия
}

\begin{abstract}
Настоящая работа направлена на обоснование необходимости разработки новых информационных систем управления жизненным циклом технологий с целью повышения эффективности деятельности промышленных предприятий. Эта необходимость была вызвана объективными процессами, происходящими в мире, а именно: глобализацией мировой экономики и дальнейшей специализацией труда, которые привели к обособлению производственных мощностей от центров по разработке новых видов продукции и исследованию рынков. В этой связи конкурентоспособность промышленных предприятий стала определяться в первую очередь эффективностью технологий, используемых в процессе производства. Однако подавляющее большинство информационных систем в настоящее время нацелено не на управление технологиями, а на управление продуктами.

Автор показывает общность и различия между системами управления жизненным циклом продукции и системами управления жизненным циклом технологии, какие конкурентные преимущества получат промышленные компании с переходом на системы управления жизненным циклом технологии. При этом данный переход не должен носить революционный характер, он может быть реализован за счет совершенствования имеющихся информационных систем, с переносом фокуса на совершенствование имеющихся и создание новых технологий. При таком переходе промышленные предприятия сохранят имеющиеся компетенции в области разработки новых видов продукции и получат дополнительный импульс развития за счет повышения эффективности используемых технологий.

Ключевые слова: информационные системы, технологии, управление, промышленность, управление предприятием, жизненный ичикл технологий, управление жизненным цүиклом технологий.
\end{abstract}

\section{Лuтература}

1. Управление промышиенными предприятиями: стратегии, механизмы, системы: моногр. / О.В. Логиновский, В.Н. Бурков, И.В. Буркова и др.; под ред. О.В. Логиновского. - М.: ИНФРА-М, $2018-410 c$.

2. Логиновский, О.В. Повышение эффективности работы предприятия на основе современных управленческих технологий и информационно-аналитических систем / О.В. Логиновский, 
К.А. Коренная // Автоматизаиия и управление промышленными предприятиями: докл. науч.техн. конф. всерос. форума «Информачионное общество-2015: вызовы и задачи». - Челябинск: Издат. иентр ЮУрГУ, 2015. - С. 4-38.

3. Новиков, Д.А. Теория управления организационными системами / Д.А. Новиков. - М.: Изд-во физ.-мат. лит., 2012. - 604 с.

4. Щербакова, Е.А. Системный подход к управлению жизненным ииклом организачии / Е.А. Щербакова // Организатор производства. - 2013. - № 3 (58). - С. $28-30$.

5. Павлов, Н.В. Управление жизненным ииклом продукта / Н.В. Павлов - СПб.: СанктПетербургский политехнический университет Петра Великого, 2014. - 219 c.

6. Зараменских, Е.П. Управление жизненным ииклом информационных систем: моногр. / Е.П. Зараменских. - Новосибирск: Изд-во ЦРНС, 2014. - 270 с.

7. Управление жизненными ииклами промышленных технологий / В.Н. Кононов, Е.С. Замбржиикая, Р.Р. Дема, М.В. Харченко // Вестник Омского ун-та. Сер. «Экономика». - 2018. № 1 (61). - C. 76-87. DOI: 10.25513/1812-3988.2018.1.76-87

8. Управление жизненным циклом продукиии / А.Ф. Колчин, М.В. Овсянников, А.Ф. Стрекалов, С.В. Сумароков. - М.: Анахарсис, 2002. - 304 c.

9. Кульга, К.С. Автоматизачия технической подготовки и управления производством на основе PLM-системы / K.C. Кульга. - М.: Машиностроение, 2008. - 275 c.

10. Saaksvuori, A. Product Lifecycle Management / A. Saaksvuori, A. Immonen. - Berlin: Springer, 2008. - 254 p. DOI: 10.1007/978-3-540-78172-1

11. Мартынов, О.Ю. Жизненный иикл технологий в производстве наукоемкой продукиии / О.Ю. Мартынов // Вектор науки Тольяттинского государственного университета. - 2012. № 1. - C. 69-72.

12. BPM CBOK Version 3.0: Guide to the Business Process Management Common Body of Knowledge / T. Benedict, N. Bilodeau, P. Vitkus et al. - Create Space Independent Publishing Platform, 2013. $-446 p$.

13. Fundamentals of Business Process Management / M. Dumas, M. Rosa, J. Mendling, H. Reijers. Berlin: Springer, 2018. - 527 p. DOI: 10.1007/978-3-662-56509-4

14. Голлай, А.В. Генезис понятия «технологическое развитие» / А.В. Голлай // Управление в современных системах. - 2018. - № 3 (19). - С. 20-24.

Голлай Александр Владимирович, канд. хим. наук, доцент кафедры информационно-аналитического обеспечения управления в социальных и экономических системах, Южно-Уральский государственный университет, г. Челябинск; alexander@hollay.ru.

Поступила в редакцию 22 февраля 2019 г.

\section{ОБРАЗЕЦ ЦИТИРОВАНИЯ}

Hollay, A.V. Need of Developing Information Systems of Managing a Technology Lifecycle of Industrial Enterprises / A.V. Hollay // Вестник ЮУрГУ. Серия «Компьютерные технологии, управление, радиоэлектроника». - 2019. - Т. 19, № 2. - С. 153-159. DOI: $10.14529 /$ ctcr190214

\section{FOR CITATION}

Hollay A.V. Need of Developing Information Systems of Managing a Technology Lifecycle of Industrial Enterprises. Bulletin of the South Ural State University. Ser. Computer Technologies, Automatic Control, Radio Electronics, 2019, vol. 19, no. 2, pp. 153-159. DOI: $10.14529 /$ ctcr190214 